\title{
Excretion of complement proteins and its activation marker C5b-9 in IgA nephropathy in relation to renal function
}

Kisara Onda ${ }^{1}$, Isao Ohsawa ${ }^{1}$, Hiroyuki Ohi ${ }^{1}$, Mariko Tamano ${ }^{1}$, Satoshi Mano ${ }^{1}$, Michiro Wakabayashi ${ }^{1}$, Akie Toki ${ }^{1}$, Satoshi Horikoshi ${ }^{1}$, Teizo Fujita ${ }^{2}$ and Yasuhiko Tomino ${ }^{1 *}$

\begin{abstract}
Background: Glomerular damage in IgA nephropathy (IgAN) is mediated by complement activation via the alternative and lectin pathways. Therefore, we focused on molecules stabilizing and regulating the alternative pathway C3 convertase in urine which might be associated with IgAN pathogenesis.
\end{abstract}

Methods: Membrane attack complex (MAC), properdin (P), factor $\mathrm{H}(\mathrm{fH})$ and Complement receptor type 1 (CR1) were quantified in urine samples from 71 patients with IgAN and 72 healthy controls. Glomerular deposition of C5, $\mathrm{fH}$ and $\mathrm{P}$ was assessed using an immunofluorescence technique and correlated with histological severity of IgAN and clinical parameters. Fibrotic changes and glomerular sclerosis were evaluated in renal biopsy specimens.

Results: Immunofluorescence studies revealed glomerular depositions of $\mathrm{C} 5, \mathrm{fH}$ and $\mathrm{P}$ in patients with IgAN. Urinary MAC, $f H$ and $P$ levels in IgAN patients were significantly higher than those in healthy controls $(p<0.001)$, but CR1 was significantly lower than that in healthy controls $(p<0.001)$. Urinary MAC and fH levels were positively correlated with serum creatinine $(\mathrm{s} C \mathrm{Cr})$, urinary $\mathrm{N}$-acetyl- $\beta$-D-glucosaminidase (u-NAG), urinary $\beta 2$ microglobulin ( $\mathrm{u}-\mathrm{Bm})$, urinary protein $(\mathrm{p}<0.001$ ), interstitial fibrosis (MAC: $\mathrm{p}<0.01, \mathrm{fH}: \mathrm{p}<0.05$ ) and the percentage of global glomerular sclerosis $(p<0.01)$. Urinary $P$ was positively correlated with $u-N A G, u-B m$, and urinary protein $(p<0.01)$.

Conclusions: Complement activation occurs in the urinary space in IgAN and the measurement of levels of MAC and $\mathrm{fH}$ in the urine could be a useful indicator of renal injury in patients with IgAN.

\section{Background}

IgA nephropathy (IgAN) is the most common form of glomerular disease worldwide. Predominant deposition of IgA1 and C3 in mesangial areas is accepted as a hallmark diagnostic feature of IgAN. Immunohistological findings on complement components showed deposits of $\mathrm{C} 3$ and properdin $(\mathrm{P})$ in the glomerular mesangial areas and the absence of $\mathrm{C} 1 \mathrm{q}$ in patients with IgAN [1-3]. Thus, it has been thought that the activation of the alternative pathway plays a crucial role in the pathogenesis of IgAN. However, recent studies revealed that $25 \%$ of patients with IgAN had mesangial deposits of mannose-binding lectin (MBL), L-ficolin, MBL-associated serine protease

\footnotetext{
* Correspondence: yasu@juntendo.ac.jp

'Division of Nephrology, Department of Internal Medicine, Juntendo University Faculty of Medicine, Tokyo, Japan

Full list of author information is available at the end of the article
}

and $\mathrm{C} 4$, suggesting that the lectin pathway activation may also be important in some IgAN patients [4-7]. In any event, activation of $\mathrm{C} 3$ and $\mathrm{C} 3$ convertase production are the key causes of histological damage induced following membrane attack complex (MAC; C5b-9) formation. MAC is produced via the activated common terminal pathway of all three complement pathways.

There are several proteins which stabilize or regulate C3 convertase activation via the alternative or lectin pathways. $\mathrm{C} 3 \mathrm{bBb}$ is an unstable form of $\mathrm{C} 3$ convertase with a halflife of 90 seconds. $\mathrm{C} 3 \mathrm{bBb}$ associates with and is stabilized by $\mathrm{P}$, to form the C3bBbP, with a half-life extended 5-10fold [8]. Factor $\mathrm{H}(\mathrm{fH})$ plays a crucial role in inhibition of the alternative pathway by the following mechanism: 1$) \mathrm{fH}$ is a cofactor for factor I (fI) in cleaving C3b to inactivate C3bi $[9,10]$ and 2) $\mathrm{fH}$ accelerates the decay of $\mathrm{C} 3 \mathrm{~b}, \mathrm{Bb}$, and C3bBbP [11]. Complement receptor type 1 (CR1;
C Biomed Central 
CD35) is a natural membrane-bound regulator and has specificity for $\mathrm{C} 3 \mathrm{~b}$ and $\mathrm{C} 4 \mathrm{~b}$ with the ability to displace the catalytic subunits from $\mathrm{C} 3$ or $\mathrm{C} 5$ convertase and to function as a co-factor for the degradation of $\mathrm{C} 3 \mathrm{~b}$ and $\mathrm{C} 4 \mathrm{~b}$ mediated by factor I $[12,13]$.

Because our previous work established that the serum levels of B, P, fH and fI in patients with IgAN were significantly higher than those in healthy controls [14], we hypothesized that targeting the alternative pathway $\mathrm{C} 3$ convertase activation could be therapeutically beneficial in IgAN. In other types of glomerular disease, such as membranous nephropathy and lupus nephritis, patients' urine contains complement regulatory proteins and MAC, amounts of which fluctuate with disease activity [15-17]. Here, we investigated these issues using urine samples from patients with IgA nephropathy, which, unlike serum, can be obtained noninvasively.

\section{Methods}

\section{Patients and controls}

Seventy-one patients with IgAN (38 males and 33 females), who had been referred to Juntendo University Hospital between March 2003 and May 2005, were enrolled. Age of these patients at the time of urine collection ranged from 16 to 67 years old $(37.8 \pm 12.8$, mean \pm SD). Normal controls were 72 healthy volunteers ( 58 males and 14 females). This study was approved by the institutional human study Ethics Committee and informed consent was obtained before participation. Histological diagnosis was classified by standard examination of renal biopsy specimens by light microscopic findings with the results of immunoglobulin and complement deposition by immunofluorescence technique. According to the Japanese Clinical Guidelines for Patients with IgAN [18], patients were divided into four groups as follows: good prognosis, relatively good prognosis, relatively poor prognosis and poor prognosis (Table 1).

\section{Laboratory data}

Serum total protein (TP), urinary protein (urinary protein $(\mathrm{mg} / \mathrm{dl}) /$ urinary creatinine $(\mathrm{mg} / \mathrm{dl}))$, urinary $\mathrm{N}$-acetyl- $\beta$-D-glucosaminidase (u-NAG), urinary $\beta_{2^{-}}$ microglobulin $(\mathrm{u}-\mathrm{Bm})$ and serum levels of urea nitrogen (SUN), and creatinine (s-Cr) were measured as part of the routine clinical analyses at the time of urine collection. Laboratory data were undertaken at the central laboratory in the Juntendo University Hospital.

\section{Glomerular deposition of Immunoglobulins, C1q, C3, C5, $\mathrm{fH}$ and $\mathrm{P}$}

Renal biopsy specimens were frozen and examined by direct immunofluorescence staining, performed using fluorescein-5-isothiocyanate-labeled rabbit anti-human IgG, IgA, IgM, C1q and C3 antisera (Dako, Denmark), goat anti-human $\mathrm{C} 5$ and $\mathrm{P}$ antisera (Nordic Immunological Laboratories, Tilburg, Netherlands), and rabbit antihuman $\mathrm{fH}$ antiserum labeled by Linkit ${ }^{\mathrm{TM}}$ Fluoro-Link (ISL, Paignton, UK). IgG, IgA, IgM, C1q and C3 were diluted to 1:50 in $0.01 \mathrm{~mol} / \mathrm{l} \mathrm{PBS}, \mathrm{ph} 7.4$, and $\mathrm{C} 5, \mathrm{fH}$ and $\mathrm{P}$ were diluted to 1:10 in the same buffer.

\section{Measurement of complement regulatory proteins and MAC in urine}

Urine samples were obtained and stored at $-80^{\circ} \mathrm{C}$ until use. Rabbit antisera to human $\mathrm{fH}, \mathrm{P}, \mathrm{CR} 1$, and purified P were kindly provided by Professor Teizo Fujita (Department of Biochemistry, Fukushima Medical University, Japan). Biotinylated anti-human properdin antibody was purchased from AntibodyShop (Gentofte, Denmark).

Urinary concentrations of $\mathrm{fH}$ and $\mathrm{MAC}$ were measured by commercially available sandwich enzyme-linked immunosorbent assay (ELISA) kits (BTA TRAK Kit, Alidex, Inc., Redmond, WA, USA, and SC5b-9 EIA, Quidel, San Diego, CA, USA). ELISA for P and CR1 were developed in our institute. Urinary $\mathrm{P}$ was quantified as described in our

Table 1 Histological severity of IgAN (Japanese Clinical Guidelines )

\begin{tabular}{cccc}
\hline & $\begin{array}{c}\text { Mesangial } \\
\text { cell } \\
\text { proliferation } \\
\text { and } \\
\text { increased } \\
\text { matrix }\end{array}$ & $\begin{array}{c}\text { Glomerulosclerosis, } \\
\text { crescent formation } \\
\text { or adhesion to } \\
\text { Bowman's capsule }\end{array}$ & Prominent changes are not seen \\
\hline $\begin{array}{c}\text { Good } \\
\text { prognosis }\end{array}$ & Slight & Absent & $\begin{array}{c}\text { Interstitium, } \\
\text { renal tubuli } \\
\text { or blood vessels }\end{array}$ \\
\hline $\begin{array}{c}\text { Relatively good } \\
\text { prognosis }\end{array}$ & Slight & $\begin{array}{c}<10 \% \text { of all } \\
\text { biopsied glomeruli }\end{array}$ & Prominent changes are not seen \\
\hline $\begin{array}{c}\text { Relatively } \\
\text { poor prognosis }\end{array}$ & $\begin{array}{c}\text { Moderate, } \\
\text { diffuse }\end{array}$ & $\begin{array}{c}10-30 \% \text { of all } \\
\text { biopsied glomeruli }\end{array}$ & $\begin{array}{c}\text { Cellular infiltration is slight in the interstitium except around some sclerosed glomeruli. } \\
\text { Tubular atrophy is slight, and mild vascular sclerosis. }\end{array}$ \\
\hline $\begin{array}{c}\text { Poor } \\
\text { prognosis }\end{array}$ & $\begin{array}{c}\text { Severe, } \\
\text { diffuse }\end{array}$ & $\begin{array}{c}>30 \% \text { of all } \\
\text { biopsied glomeruli }\end{array}$ & $\begin{array}{c}\text { Interstitial cellular infiltration and tubular atrophy, as well as fibrosis are seen. Hyperplasia } \\
\text { or degeneration may be seen in some intrarenal arteriolar walls. }\end{array}$ \\
\hline
\end{tabular}


previous report [14]. CR1 in urine was determined using 4 $\mu \mathrm{g} / \mathrm{ml}$ rabbit anti-human CR1 antibody and $0.1 \mu \mathrm{g} / \mathrm{ml}$ biotinylated mouse anti-human CR1 antibody (Ancell Corporation, Bayport, MN, USA) [19].

\section{Western blot analysis for urinary $\mathrm{fH}$}

To obtain a detectable amount of urinary $\mathrm{fH}$, the urine samples were concentrated fourfold by Ultrafree-MC Centrifugal Filter Units (Millipore, Bedford, MA, USA). Urine samples were electrophoresed on 5\% SDS-PAGE gradient gels under non-reducing conditions and the resultant bands were transferred to Immobilon ${ }^{\mathrm{TM}}$ (Millipore, Bedford, MA, USA). The immunoblots were incubated with biotinylated mouse anti-human $\mathrm{fH}$ antibody (AntibodyShop, Gentofte, Denmark), and incubated with streptavidin-peroxidase (Streptavidin-HRP, Southern Biotechnology Associates, Inc. Birmingham, AL, USA), and then developed using the ECL-plus system (Amersham Biosciences, Little Chalfont, UK).

\section{Evaluation of fibrotic changes and glomerular sclerosis}

Fibrotic changes were evaluated on Azan and MassonTrichrome-stained slides from 60 cases. Interstitial fibrosis was assessed by measuring the percentage of fibrotic (collagen-positive) area against whole area of specimen, using the KS400 Carl Zeiss image analysis system (KS400, Carl Zeiss Imaging Solutions GmbH, Hallbergmoos, Germany).

The percentage of global glomerular sclerosis as a fraction of all glomeruli was determined in 39 renal biopsy specimens by light microscopy.

\section{Statistical analysis}

Data are shown as mean \pm SD. Comparisons among the groups were performed by the Mann-Whitney U test, and comparisons of the four classifications were performed by the Bonferroni's Multiple Comparison test. Correlations among the groups were evaluated by linear regression. $\mathrm{P}$ values $<0.05$ were considered significant in all analyses.

\section{Results}

Patients' background

All patients with IgAN were classified according to the Japanese Clinical Guidelines [18] and their clinical characteristics are shown in Table 2. U-NAG levels in the poor prognosis group were significantly higher than those in the other groups $(\mathrm{p}<0.05)$. Significant differences in levels of TP, s-Cr and urinary protein were observed among the four groups. Regarding differences associated with disease severity, levels of urinary MAC were increased; especially in the poor prognosis group it was tending significantly higher than in the good prognosis group.

\section{Glomerular deposition of complement components and regulatory proteins}

Immunofluorescence technique revealed deposits of $\mathrm{C} 3$, $\mathrm{C} 5, \mathrm{fH}$ and $\mathrm{P}$ in glomeruli of IgAN patients (Figure 1). The coarse granular deposits of all these factors appeared to have a similar mesangial distribution pattern. From these results, we inferred that the alternative pathway $\mathrm{C} 3$ convertase was activated and regulated in the IgAN glomeruli.

\section{Urinary MAC and complement regulatory proteins}

Urinary complement components in IgAN patients and healthy controls are shown in Figure 2. In IgAN patients, urinary $\mathrm{MAC}, \mathrm{fH}$, and $\mathrm{P}$ levels were significantly higher than those in healthy controls (Figure 2A, B, C), whereas urinary CR1 was significantly lower (Figure 2D). Figure 3 shows the relationship between urinary MAC, fH, P, CR1 and disease severity. In particular, levels of urinary MAC

Table 2 Clinical characteristics of the patients

\begin{tabular}{|c|c|c|c|c|c|c|}
\hline $\begin{array}{l}\text { Classification } \\
\text { (The number of biopsies and range of glomeruli) }\end{array}$ & $\begin{array}{l}\text { TP } \\
(g / d l)\end{array}$ & $\begin{array}{c}\mathrm{s}-\mathrm{Cr} \\
(\mathrm{mg} / \mathrm{dl})\end{array}$ & $\begin{array}{l}\text { u-Protein } \\
(\mathrm{g} / \mathrm{g} \cdot \mathrm{Cr})\end{array}$ & $\begin{array}{c}\mathrm{u}-\mathrm{NAG} \\
\left(10^{-3} \mathrm{U} / \mathrm{mg} \cdot \mathrm{Cr}\right)\end{array}$ & $\begin{array}{c}\mathrm{u}-\mathrm{Bm} \\
(\mathrm{ng} / \mathrm{mg} \cdot \mathrm{Cr})\end{array}$ & $\begin{array}{c}\mathrm{u}-\mathrm{MAC} \\
(\mathrm{ng} / \mathrm{mg} \cdot \mathrm{Cr})\end{array}$ \\
\hline $\begin{array}{l}\text { Good prognosis } \\
(\mathrm{n}=6,7.5 \pm 4.5)\end{array}$ & $7.3 \pm 0.6$ & $0.64 \pm 0.18$ & $0.41 \pm 0.19$ & $3.6 \pm 2.3^{*}$ & $57.7 \pm 17.3$ & $0.3 \pm 0.8$ \\
\hline $\begin{array}{l}\text { Relatively good prognosis } \\
\quad(\mathrm{n}=17,15.3 \pm 9.6)\end{array}$ & $7.4 \pm 0.3^{* *}$ & $0.80 \pm 0.19$ & $0.39 \pm 0.36^{*}$ & $3.6 \pm 2.0^{*}$ & $110.2 \pm 113.1$ & $6.5 \pm 11.0$ \\
\hline $\begin{array}{l}\text { Relatively poor prognosis } \\
\quad(\mathrm{n}=30,13.0 \pm 6.9)\end{array}$ & $7.0 \pm 0.5$ & $0.72 \pm 0.23^{*}$ & $0.75 \pm 0.67$ & $4.5 \pm 2.2^{*}$ & $222.9 \pm 570.5$ & $12.1 \pm 24.9$ \\
\hline $\begin{array}{c}\text { Poor prognosis } \\
(\mathrm{n}=18,14.9 \pm 9.6)\end{array}$ & $6.8 \pm 0.4$ & $0.98 \pm 0.48$ & $1.10 \pm 0.92$ & $9.3 \pm 6.7$ & $254.4 \pm 528.3$ & $25.4 \pm 42.7$ \\
\hline $\begin{array}{c}\text { Total } \\
(\mathrm{n}=71)\end{array}$ & $7.1 \pm 0.5$ & $0.80 \pm 0.32$ & $0.72 \pm 0.70$ & $5.4 \pm 4.4$ & $189.9 \pm 458.4$ & $14.0 \pm 28.4$ \\
\hline
\end{tabular}

(mean \pm SD)

*: $p<0.05$ vs. poor prognosis,

${ }^{*}: p<0.05$ vs. relatively poor prognosis and poor prognosis

Abbreviations: TP, total protein; s-Cr, serum creatinine; u-Protein, urinary protein; u-NAG, urinary N-acetyl- $\beta$-D-glucosaminidase; $u$-Bm, u- $\beta 2$ microglobulin; u-MAC, urinary membrane attack complex 


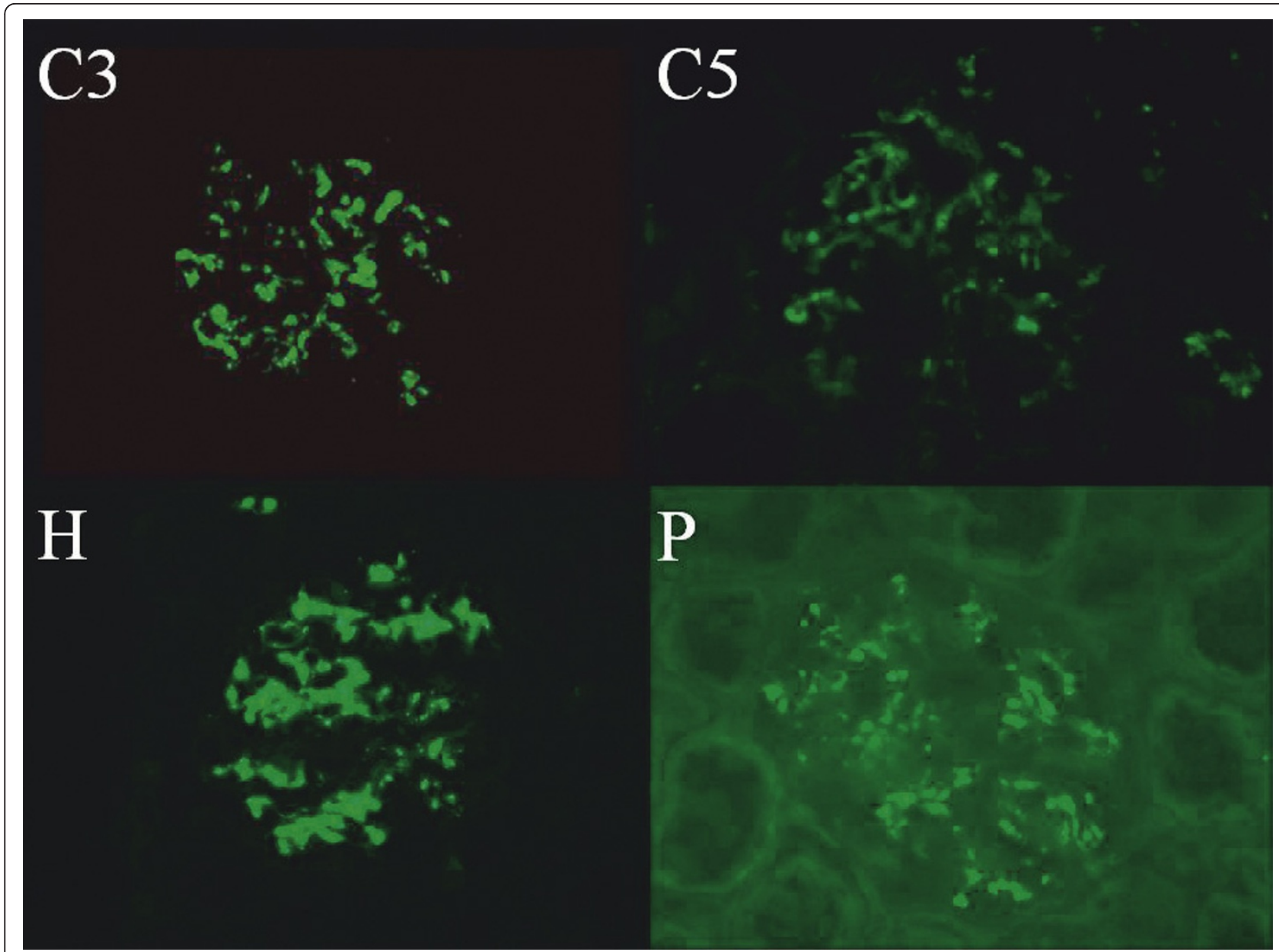

Figure 1 Glomerular deposition of $\mathrm{C} 3, \mathrm{C5}, \mathrm{fH}$ and $\mathrm{P}$ were assessed by immunofluorescence technique. Glomerular deposition of C3, C5, $\mathrm{fH}$ and $\mathrm{P}$ shows the same mesangial pattern.

and $\mathrm{fH}$ significantly increased with increased disease severity $(\mathrm{p}<0.001)$.

Correlations between urinary complement and clinical markers for renal disease were sought (Table 3). Urinary MAC was significantly correlated with $\mathrm{s}-\mathrm{Cr}(\mathrm{p}<0.01)$, u-NAG $(\mathrm{p}<0.001)$, u-Bm $(\mathrm{p}<0.001)$ and urinary protein $(\mathrm{p}<0.001)$. There was also a significant correlation between $\mathrm{fH}$ and all parameters $(\mathrm{p}<0.001)$. Levels of urinary $\mathrm{MAC}$ and $\mathrm{fH}$ dovetail with clinical disease activity. Levels of urinary CR1 were significantly correlated with $\mathrm{u}-\mathrm{Bm}(\mathrm{p}<0.01)$, but there was no significant correlation between CR1 and any other parameters.

\section{Molecular weight of urinary $\mathrm{fH}$}

The molecular weight of urinary $\mathrm{fH}$ was evaluated by Western blotting in 7 patients with levels $>50 \mathrm{U} / \mathrm{mg} \cdot \mathrm{Cr}$ (Figure 4). Serum $\mathrm{fH}$ had an estimated molecular weight of 150 $\mathrm{kDa}$ in all patients, as well as in the healthy controls. There was no $\mathrm{fH}$ in the urine of healthy controls. Urinary $\mathrm{fH}$ in
IgAN patients was also $150 \mathrm{kDa}$, except for one patient whose urine had the highest level of $\mathrm{fH}$ and contained a 42 $\mathrm{kDa}$ protein (factor $\mathrm{H}$ like protein 1: FHL-1).

\section{Urinary complement and histological changes}

Correlations between urinary complement levels and interstitial fibrosis, and between urinary complement levels and percentage of global glomerular sclerosis, were evaluated in IgAN patients (Table 4). Urinary MAC was significantly correlated with interstitial fibrosis $(\mathrm{p}<0.01)$ and the percentage of global glomerular sclerosis as a fraction of all glomeruli $(\mathrm{p}<0.01)$. Urinary $\mathrm{fH}$ levels were significantly correlated with interstitial fibrosis $(\mathrm{p}<0.05)$ and the percentage of global glomerular sclerosis $(\mathrm{p}<0.01)$.

Significant correlations were also found between interstitial fibrosis and urinary protein $(\mathrm{r}=0.421, \mathrm{p}<0.01)$, and between percentage of global glomerular sclerosis and urinary protein $(\mathrm{r}=0.339, \mathrm{p}<0.01)$. 


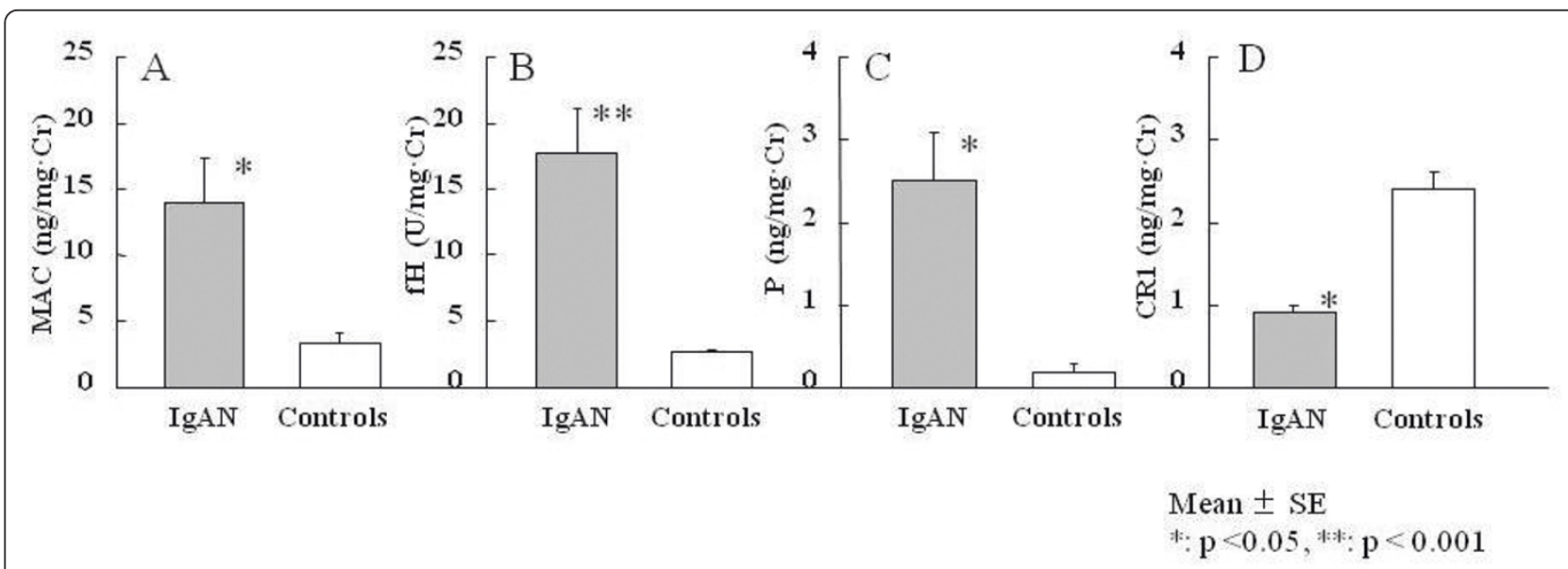

Figure 2 Urinary MAC and complement regulatory protein levels differ between patients with IgA nephropathy and healthy controls. Levels of urinary MAC, $\mathrm{fH}$, and $\mathrm{P}$ are significantly higher in IgAN patients than those in healthy controls, but CR1 is significantly lower.

\section{Discussion}

IgAN is the most common chronic glomerulonephritis with one third of patients developing progressive end-stage renal failure $[20,21]$. Although complement activation leads to tissue damage in IgAN, the role of complement regulatory proteins in the pathogenesis of IgAN has not been clearly defined. Our previous report and others documented increased serum levels of $\mathrm{fH}$ and $\mathrm{P}$ in IgAN patients and that serum levels of complement regulatory proteins reflected IgAN disease activity $[14,22]$. Based on

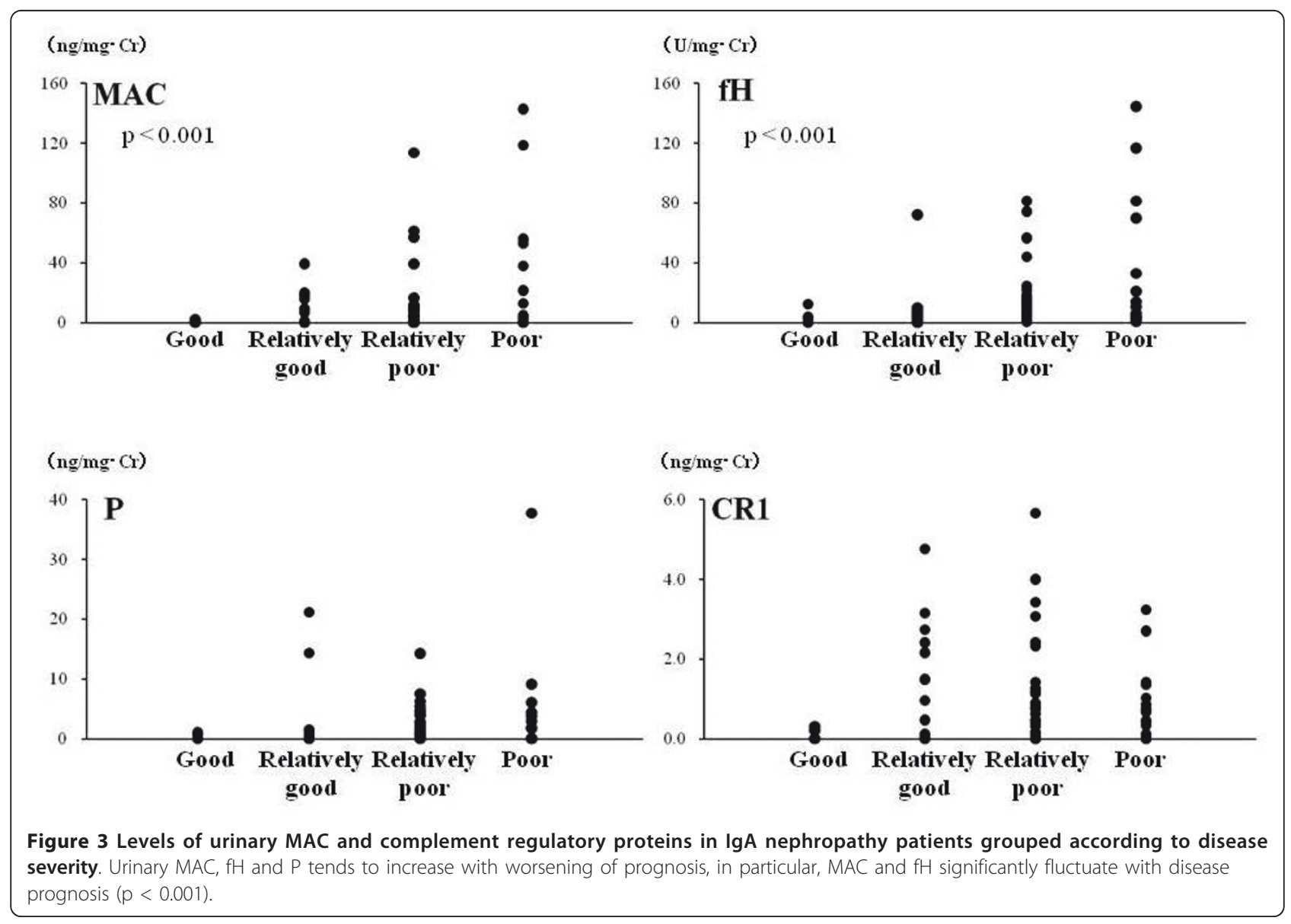


Table 3 Correlations between levels of urinary MAC and complement regulatory proteins in IgAN patients

\begin{tabular}{cccccccccc}
\hline & & MAC & & fH & & $\mathbf{P}$ & & CR1 \\
\hline & $\mathbf{r}$ & $\mathbf{p}$ & $\mathbf{r}$ & $\mathbf{p}$ & $\mathbf{r}$ & $\mathbf{p}$ & $\mathbf{r}$ & $\mathbf{p}$ \\
\hline s-Cr & 0.297 & $\mathrm{p}<0.01$ & 0.531 & $\mathrm{p}<0.001$ & 0.192 & $\mathrm{p}=0.102$ & -0.174 & $\mathrm{p}=0.137$ \\
\hline u-NAG & 0.589 & $\mathrm{p}<0.001$ & 0.633 & $\mathrm{p}<0.001$ & 0.419 & $\mathrm{p}<0.001$ & 0.491 & $\mathrm{p}=0.481$ \\
\hline u-Bm & 0.414 & $\mathrm{p}<0.001$ & 0.384 & $\mathrm{p}<0.001$ & 0.367 & $\mathrm{p}<0.01$ & 0.323 & $\mathrm{p}<0.01$ \\
\hline u-Protein & 0.458 & $\mathrm{p}<0.001$ & 0.645 & $\mathrm{p}<0.001$ & 0.502 & $\mathrm{p}<0.001$ & -0.181 & $\mathrm{p}=0.122$ \\
\hline
\end{tabular}

Abbreviations: MAC, membrane attack complex; $\mathrm{fH}$, factor $\mathrm{H}$; $\mathrm{P}$, properdin; $\mathrm{CR} 1$, complement receptor 1 ; s-Cr, serum creatinine; $\mathrm{u}-\mathrm{NAG}$, urinary $\mathrm{N}$-acetyl- $\beta$-Dglucosaminidase; $\mathrm{u}-\mathrm{Bm}$, u- $\beta 2$ microglobulin; u-Protein, urinary protein

these findings, we planned to evaluate the significance of urinary complement components in the pathogenesis of IgAN.

In other renal diseases, strong associations of urinary $\mathrm{fH}$ and MAC levels with disease progression have been demonstrated (15-17). Recently, Zang et al. proposed that urinary $\mathrm{fH}$ in patients with IgAN may be a useful biomarker to evaluate kidney injury [23]. In that report, the analysis was limited to urinary $\mathrm{fH}$. Here, we extend our evaluation to other proteins, namely, P, CR1 and MAC. We found that levels of urinary MAC, $\mathrm{fH}$ and $\mathrm{P}$ in patients with IgAN were significantly higher than those in healthy controls. Furthermore, urinary MAC and $\mathrm{fH}$ levels were significantly increased with increasing disease severity. Urinary MAC levels reflected disease state in patients with IgAN, as is the case in other nephropathies [24]. Urinary $\mathrm{fH}$ and $\mathrm{P}$, which are involved in the regulation and stabilization of the alternative pathway C3 convertase, might also be associated with renal damage. Although only 4 patients had taken steroids when they were collected the urine samples, results of complement components presented not particular tendency.

In renal disease, renal function is closely related to tubulo-interstitial injury, part of which is due to MAC formation on tubular epithelial cells [25]. Indeed, urinary $\mathrm{fH}$ and P levels were strongly correlated with u-NAG and might reflect the occurrence of intra-tubular activation of C3. In additional work, we did find significant correlations between urinary fH and $\mathrm{P}(\mathrm{p}<0.001)$, $\mathrm{fH}$ and MAC ( $<<$ $0.001)$, and $P$ and MAC $(p<0.001)$ (data not shown).

The human $\mathrm{fH}$ family consists of seven multi-domain and multifunctional serum proteins, including $\mathrm{fH}$ itself (MW $150 \mathrm{kDa}$ ), factor $\mathrm{H}$-like protein 1 (FHL-1) (MW 42 $\mathrm{kDa}$ ) and five factor $\mathrm{H}$-related proteins (FHR-1, -2, -3, -4 and -5) [26]. This study demonstrated that $\mathrm{fH}$, a $150 \mathrm{kDa}$ protein, was detected in patients' urine samples, but lower MW members of this family were not detected in IgAN, with the exception of one patient with FHL-1. Because human mesangial cells and proximal tubular epithelial cells are capable of producing $\mathrm{fH}[27,28]$, urinary $\mathrm{fH}$ might be derived from glomeruli and/or tubules, not from the blood.

Previous studies showed that synthesis of membranebound CR1 on the podocytes is reduced in patients with advanced glomerular disease $[29,30]$. Urinary CR1 was released from podocytes, and did not originate from erythrocyte CR1 and soluble CR1 [31]. Likewise, as established here, urinary CR1 in patients with IgAN was significantly lower than in healthy controls.

There was a significant correlation between interstitial fibrosis and the percentage of global glomerular sclerosis as a fraction of all glomruli $(\mathrm{p}<0.01)$. Thus, tubulointerstitial damage may be affected by glomerular injury. There were significant correlations between interstitial fibrosis and urinary protein, and between the percentage of global glomerular sclerosis and urinary protein. It was previously

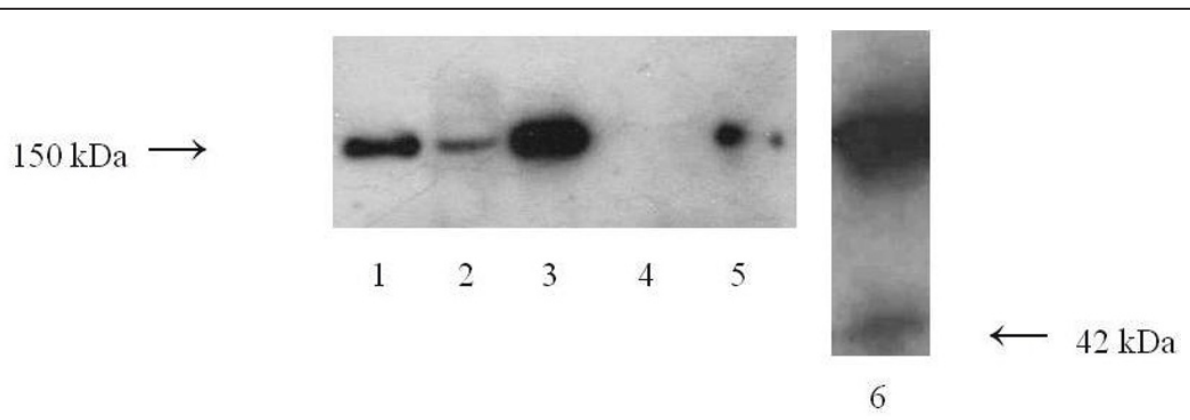

Figure 4 Detection of $\mathrm{fH}$ in urine and serum samples by Western blotting. Representative results show molecular weight assessments for $\mathrm{fH}$. Lane 1: purified fH, lane 2: urine a from patient, 3: serum from the same patient, 4: urine from a healthy control, 5: serum from a healthy control, 6: urine from the patient with the highest level of urinary $\mathrm{fH}$. 
Table 4 Correlations between urinary complement levels and fibrosis in IgAN patients

\begin{tabular}{ccccc}
\hline \multicolumn{2}{c}{ Interstitial fibrosis } & $\mathbf{p}$ & $\begin{array}{c}\text { Percentage of global glomerular sclerosis } \\
\text { as a fraction of all glomeruli }\end{array}$ \\
\hline MAC & $\mathbf{r}$ & $\mathrm{r}$ & $\mathbf{p}$ & $\mathrm{p}$ \\
fH & 0.476 & $\mathrm{p}<0.01$ & 0.361 & $\mathrm{p}$ \\
$\mathrm{P}$ & 0.383 & $\mathrm{p}<0.05$ & 0.411 & $\mathrm{p}<0.01$ \\
CR1 & 0.310 & $\mathrm{p}=0.054$ & 0.215 & $\mathrm{p}=0.099$ \\
U-protein & -0.179 & $\mathrm{p}=0.279$ & -0.158 & $\mathrm{p}=0.229$ \\
\hline
\end{tabular}

Abbreviations: MAC, membrane attack complex; $\mathrm{fH}$, factor $\mathrm{H} ; \mathrm{P}$, properdin; $\mathrm{CR} 1$, complement receptor 1; U-protein, Urinary protein

considered that the presence of urinary protein reflected glomerular damage and interstitial fibrosis. Therefore, interstitial fibrosis and the percentage of global glomerular sclerosis might be a marker of renal damage. Urinary $\mathrm{fH}$ and MAC were significantly correlated with interstitial fibrosis and the percentage of global glomerular sclerosis. Moreover, MAC showed a better correlation with interstitial fibrosis than did urinary protein, and $\mathrm{fH}$ correlated better with global sclerosis than urinary protein in patients with IgAN. Urinary fH showed a better correlation with serum creatinine, urinary NAG, urinary protein and global sclerosis than urinary MAC in patients with IgAN. It is proposed that in fact, $\mathrm{fH}$ might not regulate complement activation and subsequent formation of MAC. Therefore, MAC formation and renal damage might occur in IgAN. Further research is needed to clarify whether the relationships between urinary $\mathrm{fH}$ and complement activation might recapitulate in other types of glomerulonephritis.

\section{Conclusions}

Complement activation occurs in the urinary space in IgAN and the measurement of levels of MAC and $\mathrm{fH}$ in the urine could be a useful indicator of renal injury in patients with IgAN.

\section{Acknowledgements}

We are very grateful to by Ms. Shibata Terumi for technique support.

\section{Author details}

'Division of Nephrology, Department of Internal Medicine, Juntendo University Faculty of Medicine, Tokyo, Japan. ${ }^{2}$ Department of Immunology, Fukushima Medical University School of Medicine, Fukushima, Japan.

\begin{abstract}
Authors' contributions
$\mathrm{KO}$ collected samples, carried out the study, analyzed the data and wrote the manuscript. $\mathrm{IO}$ and $\mathrm{HO}$ principal investigator advised on the study and reviewed the manuscript. MT advised the experimental methods. SM and MW helped to collect samples. AT helped evaluation of fibrotic change and glomerular sclerosis. SH participated in the design of the study. TF gave us rabbit antisera to human $\mathrm{fH}, \mathrm{P}, \mathrm{CR} 1$ and purified $\mathrm{P}$. $\mathrm{YT}$ primary principal investigator advised on the study. All authors have read and approved the final manuscript.
\end{abstract}

\section{Competing interests}

We (Kisara Onda, Isao Ohsawa, Hiroyuki Ohi, Mariko Tamano, Satoshi Mano, Michiro Wakabayashi, Akie Toki, Satoshi Horikoshi, Teizo Fujita and Yasuhiko Tomino) declare no conflict of interest in this study.
Received: 30 May 2011 Accepted: 23 November 2011 Published: 23 November 2011

\section{References}

1. Shirai T, Tomino $Y$, Sato M, Yoshiki T, Itoh T: IgA nephropathy: clinicopathology and immunopathology. Contrib Nephrol 1978, 9:88.

2. Burkholder PM, Zimmermans SW, Moorthy AV: A clinicopathologic study of natural history of mesangial IgA nephropathy. Glomerulonephritis, Japan Medical Research Foundation Tokyo, Univ. of Tokyo Press 1979, 143.

3. Sakai O, Kitajima T, Kawamura K, Ueda Y: Clinicopathological studies on IgA glomerulonephritis. Glomerulonephritis, Japan Medical Research Foundation Tokyo, Univ. of Tokyo Pres 1979, 167.

4. Endo M, Ohi H, Ohsawa I, Fujita T, Matsushita M, Fujita T: Glomerular deposition of mannose-binding lectin (MBL) indicates a novel mechanism of complement activation in IgA nephropathy. Nephrol Dial Transplant 1998, 13:1984-90.

5. Endo M, Ohi H, Satomura A, Hidaka M, Ohsawa I, Fujita T, Kanmatsuse K, Matsushita M, Fujita T: Regulation of in situ complement activation via the lectin pathway in patients with IgA nephropathy. Clinical Nephrology 2001, 55:185-191.

6. Roos A, Rastaldi MP, Calvaresi N, Oortwijn BD, Schlagwein N, van GijlswijkJanssen DJ, Stahl GL, Matsushita M, Fujita T, van Kooten C, Daha MR: Glomerular activation of the lectin pathway of complement in $\lg \mathrm{A}$ nephropathy is associated with more severe renal disease. $J$ Am Soc Nephrol 2006, 17:1724-1734.

7. Roos A, Bouwman LH, Gulswijk-Janssen DJ, Faber-Krol MC, Stahl GL, Daha MR: Human IgA activates the complement system via the mannanbinding lectin pathway. J Immunol 2001, 167:2861-2868.

8. Fearon DT, Austen KF: Properdin: binding to C3b and stabilization of the C3b-dependent C3 convertase. J Exp Med 1975, 142:856-863.

9. Whaley K, Ruddy S: Modulation of C3b hemolytic activity by a plasma protein distinct from C3b inactivator. Science 1976, 193(4257):1011-3.

10. Pangburn MK, Schreiber RD, Müller-Eberhard HJ: Human complement C3b inactivator: isolation, characterization, and demonstration of an absolute requirement for the serum protein beta1 $\mathrm{H}$ for cleavage of $\mathrm{C} 3 \mathrm{~b}$ and $\mathrm{C} 4 \mathrm{~b}$ in solution. J Exp Med 1977, 146(1):257-70.

11. Weiler JM, Daha MR, Austen KF, Fearon DT: Control of the amplification convertase of complement by the plasma protein beta1H. Proc Natl Acad Sci USA 1976, 73(9):3268-72.

12. Klickstein LB, Wong WW, Smith JA, Weis JH, Wilson JG, Fearon DT: Human $\mathrm{C} 3 \mathrm{~b} / \mathrm{C} 4 \mathrm{~b}$ receptor (CR1). Demonstration of long homologous repeating domains that are composed of the short consensus repeats characteristics of C3/C4 binding proteins. J Exp Med 1987, 165(4):1095-112.

13. Miwa T, Song WC: Membrane complement regulatory proteins: insight from animal studies and relevance to human diseases. Int Immunopharmacol 2001, 1(3):445-59.

14. Onda K, Ohi H, Tamano M, Ohsawa I, Wakabayashi M, Horikoshi S, Fujita T, Tomino Y: Hypercomplementemia in adult patients with IgA nephropathy. J Clin Lab Anal 2007, 21:77-84

15. Ogrodowski JL, Hebert LA, Sedmak D, Cosio FG, Tamerius J, Kolb W: Measurement of SC5b-9 in urine in patients with the nephritic syndrome. Kidney Int 1991, 40:1141-1147.

16. Tamano M, Fuke $Y$, Endo M, Ohsawa I, Fujita T, Ohi H: Urinary complement factor $\mathrm{H}$ in renal disease. Nephron 2002, 92:705-707. 
17. Endo M, Fuke $Y$, Tamano M, Hidaka M, Ohsawa I, Fujita T, Ohi H: Glomerular deposition and urinary excretion of complement factor $\mathrm{H}$ in idiopathic membranous nephropathy. Nephron Clin Pract 2004, 97: c147-c153.

18. Tomino Y, Sakai H: Clinical guidelines for immunoglobulin A ( $\lg A)$ nephropathy in Japan, second version. Clin Exp Nephrol 2003, 7:93-97.

19. Tamano M, Ohi H, Sudo S, Tomino Y: Quantitative polymorphism of complement receptor type 1 (CR1) in patients undergoing haemodialysis. Nephrol Dial Transplant 2004, 19(6):1467-73.

20. D'amico G: The commonest glomerulonephritis in the world: IgA nephropathy. Q J Med 1987, 64:709-727.

21. Johnston PA, Brown JS, Braumholtz DA, Davison AM: Clinicopathological correlations and long-term follow-up of 253 United Kingdom patients with IgA nephropathy. A report from the MRC Glomerulonephritis Registry. Q J Med 1992, 84:619-627.

22. Julian BA, Wyatt RJ, McMorrow RG, Galla JH: Serum complement proteins in IgA nephropathy. Clin Nephrol 1983, 20:251-258.

23. Zhang JJ, Jiang L, Liu G, Wang SX, Zou WZ, Zhang H, Zhao MH: Levels of urinary complement factor $\mathrm{H}$ in patients with $\lg \mathrm{A}$ nephropathy are closely associated with disease activity. Scand J Immunol 2009, 69(5):457-64.

24. Nangaku M, Shankland SJ, Couser WG: Cellular response to injury in membranous nephropathy. J Am Soc Nephrol 2005, 16(5):1195-1204.

25. Abbate M, Zoja C, Corna D, Rottoli D, Zanchi C, Azzollini N, Tomasoni S, Berlingeri S, Noris M, Morigi M, Remuzzi : Complement-mediated dysfunction of glomerular filtration barrier accelerates progressive renal injury. J Am Soc Nephrol 2008, 19(6):1158-67.

26. Cheng ZZ, Corey MJ, Parepalo M, Majno S, Hellwage J, Zipfel PF, Kinders RJ, Raitanen $\mathrm{M}$, Meri S, Jokiranta TS: Complement factor $\mathrm{H}$ as a marker for detection of bladder cancer. Clin Chem 2005, 51:856-863.

27. van den Dobbelsteen ME, Verhasselt $V$, Kaashoek JG, Timmerman JJ, Schroeijers WE, Verweij CL, van der Woude FJ, van Es LA, Daha MR: Regulation of $\mathrm{C} 3$ and factor $\mathrm{H}$ synthesis of human glomerular mesangial cells by IL-1 and interferon -gamma. Clin Exp Immunol 1994, 95:173-180.

28. Gerritsma JS, Gerritsen AF, De Ley M, van Es LA, Daha MR: Interferongamma induces biosynthesis of complement components C2, C4 and factor H by human proximal tubular epithelial cells. Cytokine 1997, 9:276-283.

29. Iida K, Koyama A, Nakamura H, Inage H, Narita M, Tojyo S, Kamisato J, Fujita T, Tamura N: Abnormal expression of complement receptor (CR1) in IgA nephritis: increase in erythrocytes and loss on glomeruli in patients with impaired renal function. Clin Immunol Immunopathol 1983, 40:393-400.

30. Moll S, Miot S, Sadallah S, Gudat F, Mihatsch MJ, Schifferli JA: No complement receptor 1 stumps on podocytes in human glomerulopathies. Kidney Int 2001, 59:160-168.

31. Pascual M, Steiger G, Sadallah S, Paccaud JP, Carpentier JL, James $R$ Schifferli JA: Identification of Membrane-bound CR1 (CD35) in Human Urine: Evidence for Its Release by Glomerular Podocytes. J Exp Med 1994, 179:889-899.

\section{Pre-publication history}

The pre-publication history for this paper can be accessed here: http://www.biomedcentral.com/1471-2369/12/64/prepub

doi:10.1186/1471-2369-12-64

Cite this article as: Onda et al:: Excretion of complement proteins and its activation marker C5b-9 in IgA nephropathy in relation to renal function. BMC Nephrology 2011 12:64.

\section{Submit your next manuscript to BioMed Central and take full advantage of:}

- Convenient online submission

- Thorough peer review

- No space constraints or color figure charges

- Immediate publication on acceptance

- Inclusion in PubMed, CAS, Scopus and Google Scholar

- Research which is freely available for redistribution

Submit your manuscript at www.biomedcentral.com/submit
Biomed Central 